\title{
Legalitas Perizinan Kawasan Wisata Sebagai Upaya Pengembangan Desa Wisata
}

\author{
Aktieva Tri Tjitrawati, Rizky Amalia, Fairuz Zahirah Zihni Hamdan \\ aktieva.tri@fh.unair.ac.id \\ Universitas Airlangga
}

\begin{abstract}
Keywords: $\quad$ Abstract
Tourism; Villages; One of the Government's efforts to develop the tourism sector is to line up in villages. Permits; Business Some villages that have natural potential have been developed into tourist villages. The Contract. development of tourist villages is not only in nature which is the attraction but also can be a means of education that must be optimized. Gerbo Village is one of the villages in the Pasuruan area that seeks to develop its educational tourism. An understanding of the legal aspects, including permits, business contracts, and so on, needs to be given to village officials, tourism awareness groups, and the local community. This goal is intended as a preventive effort to prevent legal problems that may arise in the future.
\end{abstract}

\section{Kata Kunci: $\quad$ Abstrak}

Kepariwisataan; Salah satu upaya Pemerintah untuk pengembangan sektor kepariwisataan Desa; Perizinan; Kontrak Bisnis. adalah berlini pada desa. Beberapa desa-desa yang mempunyai potensi alam di kembangkan menjadi desa wisata. Pengembangan desa wisata tidak hanya pada alam yang menjadi daya tarinya, namun juga bisa menjadi sarana edukasi yang harus dioptimalkan, Hal inilah yang dilakukan oleh Desa Gerbo, salah satu desa di kawasan Pasuruan yang berupaya untuk mengembangkan wisata edukasi yang dimiliki. Pemahaman mengenai aspek hukum yang meliputi perizinan, kontrak bisnis, dan sebagainya perlu untuk diberikan bagi perangkat desa, kelompok sadar wisata dan juga masyarakat setempat. Tujuan tersebut diperuntukkan sebagai upaya preventif untuk mencegah problematikaproblematika hukum yang kemungkinan timbul di kemudian hari.

Copyright () 2022 Aktieva Tri Tjitrawati, Rizky Amalia, Fairuz Zahirah Zihni Hamdan. (c) (1)

\section{Pendahuluan}

Pariwisata merupakan aktivitas yang erat kaitannya dengan perekonomian sekaligus interaksi masyarakat baik domestik maupun mancanegara. Adanya kemudahan akses melalui globalisasi, memunculkan ketertarikan untuk melakukan kunjungan ke daerah lain selain tempat tinggalnya, baik untuk berbisnis maupun sekedar berlibur. Hal ini merupakan peluang sekaligus tantangan bagi pemerintah untuk menyelenggarakan aktivitas pariwisata guna meningkatkan perekonomian rakyat. Globalisasi mengarahkan pada peningkatan perekonomian yang signifikan melalui sektor pariwisata. Tak hanya meningkatkan perekonomian, sektor pariwisata juga memiliki peran 
penting lainnya yakni meningkatkan hubungan bilateral maupun multilateral antara negara maju dengan negara berkembang. ${ }^{1}$

Pengembangan pariwisata dapat dilakukan oleh suatu negara secara mandiri, atau secara bersama-sama melalui model kerja sama dengan negara lain. ${ }^{2}$ Pengembangan wisata yang dilakukan suatu daerah secara mandiri, tidak serta merta hanya dilakukan daerah tersebut. Tetapi juga melibatkan pemerintah pusat dan daerah serta masyarakat sekitar. Pemerintah Indonesia dalam rangka mengatur perihal aktivitas pariwisata telah mengeluarkan Undang-Undang No. 10 Tahun 2009 tentang Kepariwisataan (selanjutnya disebut UU Kepariwisataan). Berdasarkan undang-undang tersebut, pembangunan kepariwisataan dilakukan dengan berlandaskan pada asas manfaat, kekeluargaan, adil dan merata, keseimbangan, kemandirian, kelestarian, partisipatif, berkelanjutan, demokratis, kesetaraan dan kesatuan. Asas-asas tersebut juga sebagai wujud dari pelaksanaan pembangunan pariwisata dengan memperhatikan keanekaragaman, sifat khas dan keunikan budaya dan alam, serta kebutuhan manusia untuk berwisata.

Sebagai negara yang memiliki kekayaan alam dan budaya yang berlimpah serta beragam, Indonesia memiliki potensi yang sangat besar dalam bidang pariwisata. ${ }^{3}$ Keberagaman tersebut menjadi daya tarik bagi sejumlah wisatawan baik domestik maupun mancanegara untuk berkunjung ke daerah-daerah di Indonesia. Hal ini dapat dilihat dari sumbangan angka dari bidang pariwisata terhadap angka Pendapatan Domestik Bruto (PDB) Nasional sebesar 10\% dari tahun 2015 hingga tahun $2019 .{ }^{4} \mathrm{Hal}$ ini menjadikan bidang pariwisata menduduki peringkat keempat sebagai penyumbang pendapatan nasional Indonesia setelah bidang pertambangan (migas, kelapa sawit, dan batu bara) sebesar 93\%. Tak hanya

\footnotetext{
${ }^{1}$ Mahadiansar, 'Implementasi Kebijakan Pengembangan Pariwisata Berkelanjutan Berbasis Network Governance (Studi Di Kabupaten Bintan, Provinsi Kepulauan Riau)’ (Universitas Brawijaya 2021).[1].

${ }^{2}$ Anton Minardi and others, 'Indonesian Tourism Diplomacy to India' (2020) 1 Indonesian Journal of Tourism and Leisure.[33].

${ }^{3}$ Firdaus, 'Potency of Integrated Cultural Tourism Development at Maninjau Lake Area, West Sumatera' (2018) 34 MIMBAR : Jurnal Sosial dan Pembangunan.[72].

${ }^{4}$ Badan Pariwisata dan Ekonomi Kreatif Republik Indonesia, 'Laporan Tahunan Kementerian Pariwisata Dan Ekonomi Kreatif 2016-2020’ (2020) dalam Mahadiansar, Op.Cit.
} 
itu, bidang pariwisata menyumbang 9,8 juta pekerjaan atau setara $8,4 \%$ kepada bidang ketenagakerjaan. ${ }^{5}$ Berikut merupakan gambaran terhadap peningkatan jumlah kunjungan wisatawan ke Indonesia dari tahun 2015 hingga tahun 2019.

Grafik Angka Kunjungan Wisatawan ke Indonesia 2015-2019

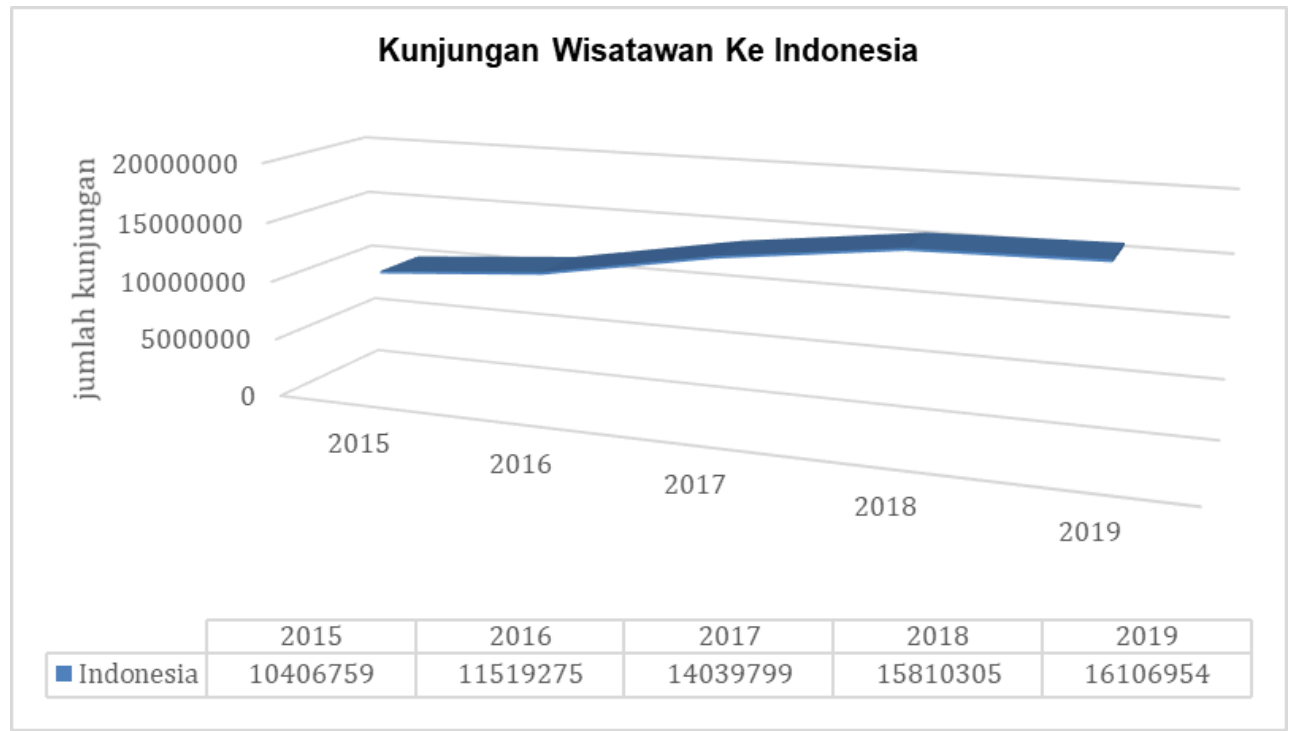

Sumber: Badan Pusat Statistik Republik Indonesia, 2020.

Peningkatan jumlah kunjungan wisatawan ke Indonesia, tidak dapat dilepaskan dari keberadaan desa-desa di daerah yang kini dikembangkan menjadi desa wisata. Desa wisata merupakan bentuk industri pariwisata berupa kegiatan perjalanan wisata ke suatu desa untuk mendorong wisatawan menggunakan produk dari desa tersebut, meliputi angkutan wisata, atraksi wisata, akomodasi pariwisata, dan produk kerajinan desa tersebut. ${ }^{6}$ Salah satu desa pariwisata di Indonesia adalah Desa Gerbo.

Desa Gerbo merupakan desa yang terletak di lereng gunung Bromo yang mana secara geografis letak Desa Gerbo sangat strategis sebagai kawasan perkebunan yang bersinergi dengan pertanian. Saat ini Desa Gerbo merupakan salah satu desa wisata yang kerap dijadikan tempat singgahlah wisatawan

\footnotetext{
${ }^{5}$ ibid.

${ }^{6}$ Ernie Yuliati and Djoko Suwandono, 'Arahan Konsep Dan Strategi Pengembangan Kawasan Desa Wisata Nongkosawit Sebagai Destinasi Wisata Kota Semarang' (2016) 2 Ruang.[266].
} 
yang hendak bepergian ke Gunung Bromo. ${ }^{7}$ Mayoritas masyarakat Desa Gerbo bermata pencaharian sebagai petani dan pedagang. Dari segi kesenian dapat kita lihat pengembangan seperti Pencak Silat, Laro, dan lain-lain. Potensi yang Lari luar biasa yang dimiliki Desa Gerbo baik di bidang pertanian dan kesenian membuat masyarakat Gerbo mengembangkan suatu komunitas bernama Flanker yang telah berdiri dari tahun 1996 yang mana merupakan pencetus desa wisata edukasi dan budaya di Desa Gerbo yang bernama Lembah Gunung Tumpeng. Konsep tersebut diambil dari adanya sinergi antara petani, pedagang dan juga para seniman dalam pengembangan pariwisata di Desa Gerbo. Dengan adanya sinergi tersebut wisatawan pun dapat diajak berwisata dan belajar terkait bercocok tanam secara adat dan menikmati kebudayaan, kesenian, dan belajar bertani serta sekaligus dapat secara langsung membeli hasil pertanian. Sinergi kebudayaan, kesenian, pertanian dan perdagangan yang terdapat di Desa Gerbo merupakan aspek pariwisata yang dapat terus dikembangkan.

Desa Gerbo sebagai desa wisata edukasi dan budaya dalam menjalankan usaha pariwisata dan prinsip tata-kelola pariwisata yang baik maka salah satunya diperlukan suatu izin pariwisata yang mana merupakan aspek legalitas untuk membuktikan bahwa usaha pariwisata yang dijalankan tidak melanggar hukum. Kelengkapan lainnya yang diperlukan dalam usaha pariwisata yang memanfaatkan alam maka seperti salah satunya pertanian maka diperlukan dokumen lingkungan berupa Upaya Pengelolaan Lingkungan Hidup dan Upaya Pemantauan Lingkungan Hidup (UKLUPL) sebagai salah satu syarat dalam menjalankan usaha. Sementara saat ini proses perizinan baik dalam bidang pariwisata maupun lingkungan telah terdapat regulasi baru yaitu Peraturan Pemerintah Nomor 24 Tahun 2018 tentang Pelayanan Perizinan Berusaha Terintegrasi Secara Elektronik (Selanjutnya disebut PP OSS) dan ditindaklanjuti dengan ditetapkannya peraturan pelaksanaan terkait pelayanan perizinan terintegrasi secara elektronik sektor pariwisata melalui Peraturan Menteri Pariwisata Republik Indonesia Nomor 10

\footnotetext{
7 Pemerintah Desa Gerbo, 'Sejarah Desa Gerbo' < https://pemerintahdesagerbo.blogspot. com/2020/09/profil-desagerbo_7.html?m=1> diakses 7 Oktober 2021.
} 
Tahun 2018 tentang Pelayanan Perizinan Berusaha Terintegrasi Secara Elektronik Sektor Pariwisata (selanjutnya disebut Permenpar No. 10/2018)

Adanya regulasi baik PP OSS maupun Permenpar No. 10/2018, maka proses perizinan pariwisata dari perusahaan perorangan, mikro, kecil, menengah dan besar maupun perusahaan lokal dan asing melakukan pendaftaran melalui Online Single Submission (OSS) yang mana merupakan suatu sistem yang baru terkait proses pendaftaran yang dilakukan melalui suatu sistem elektronik yang terintegrasi. Pada tahun 2020 dikarenakan terdapat suatu pembaruan pada sistem OSS menjadi versi 1.1 maka para pelaku usaha yang telah memiliki NIB (Nomor Induk Berusaha) diwajibkan untuk melakukan pembaruan dara, dan bagi yang belum memiliki diwajibkan untuk melakukan pendaftaran sesegera mungkin. ${ }^{8}$

Sayangnya, meski mayoritas dari masyarakat Desa Gerbo telah menjalankan sekaligusmengembangkandesa wisata, banyakdarimerekayang belum memahami prosedur maupun hal-hal yang dibutuhkan untuk mengurus perizinan Kawasan wisata. Sebagian dari masyarakat Desa Gerbo belum mengetahui dokumen apa saja yang diperlukan untuk menjalankan usaha pariwisata. Adanya PP OSS menjadikan proses perizinan sudah tidak lagi berjalan secara konvensional seperti sebelumnya, tetapi sudah menjadi proses digital. PP OSS mewajibkan pelaku usaha yang ingin mendaftarkan usaha pariwisatanya wajib melalui OSS, baik bagi yang telah melakukan pendaftaran sebelumnya untuk lebih lanjut dilakukan pembaruan data, ataupun bagi pelaku usaha yang pertama kali mendaftarkan kegiatan usahanya. Hal ini semakin membuat sebagian masyarakat Desa Gerbo kesulitan untuk mengurus perizinan Kawasan wisata karena kurangnya pemahaman mereka mengenai hal ini.

OSS merupakan perizinan berusaha yang ditujukan kepada pelaku usaha, termasuk usaha pariwisata melalui sistem elektronik yang terintegrasi. Adanya kemajuan teknologi merupakan salah satu faktor adanya peluncuran OSS yang bertujuan untuk menjamin kepastian hukum bagi pelaku usaha serta menjadi

8 Badan Koordinasi Penanaman Modal, 'OSS/Sistem Pelayanan Perizinan Berusaha Terintegrasi Secara Elektronik' <https:/ / oss.go.id/> diakses 8 Oktober 2021. 
sumber informasi perizinan usaha bersektor pariwisata yang terintegrasi, tidak lagi rumit dan sulit. Adanya OSS ini sesungguhnya akan memberikan banyak kemudahan bagi para pelaku usaha, termasuk usaha pariwisata. Para pelaku usaha pariwisata akan lebih mudah untuk mengurus perizinan berusaha baik prasyarat untuk melakukan usaha, izin usaha, maupun izin operasional untuk kegiatan operasional usaha. ${ }^{9}$ Selain itu, pelaku usaha akan lebih mudah untuk terhubung dengan semua stakeholder dan memperoleh izin secara aman dan cepat. ${ }^{10}$ Oleh karena itu, artikel ini bertujuan untuk memberikan ulasan sekaligus solusi terhadap pengembangan Kawasan wisata di Desa Gerbo sebagai Desa Wisata melalui Perizinan Berbasis OSS. Artikel ini akan membahas 2 (dua) isu hukum, yaitu pengembangan potensi desa wisata di Indonesia dan pelaksanaan OSS pada Izin Usaha Pariwisata.

\section{Metode Penelitian}

Penelitian ini merupakan penelitian yang bersifat normatif dengan melakukan kajian mengenai permasalahan hukum yang terdapat dalam penyelenggaraan pengembangan kawasan desa wisata berkaitan dengan aspek legalitas perizinan. Pendekatan yang digunakan adalah pendekatan undang-undang (statute approach) dengan menelaah peraturan perundangundangan dan regulasi yang bersangkut paut dengan permasalahan hukum yang sedang dikaji, dan pendekatan konseptual (conceptual approach) dengan menguraikan dan menganalisis permasalahan hukum menggunakan pendapat para ahli (doktrin). ${ }^{11}$ Kedua pendekatan tersebut digunakan untuk mencari suatu kerangka hukum ideal yang dalam hal ini akan difokuskan terhadap pengembangan desa wisata yang memberikan perlindungan bagi para pihak terkait.

${ }^{9}$ Tim Percepatan Pengembangan Homestay Desa Wisata, 'Panduan Pengembangan Homestay Desa Wisata Untuk Masyarakat' (2018).[60].

${ }^{10}$ ibid.

${ }^{11}$ Peter Mahmud Marzuki, Penelitian Hukum: Edisi Revisi (Prenada Media 2017).[93]. 


\section{Pengembangan Potensi Desa Wisata di Indonesia}

Industri pariwisata memiliki potensi yang kuat untuk merevitalisasi masyarakat desa, antara lain dengan meningkatkan pertumbuhan ekonomi dan memberikan kesempatan kerja. ${ }^{12}$ Masyarakat dan pakar lokal telah lama percaya pada gagasan memanfaatkan pariwisata sebagai cara untuk mengurangi kemiskinan. Saat ini, baik wisatawan maupun pelaku usaha pariwisata telah mulai memberdayakan wisata lokal yang lebih dekat dengan alam dan budaya setempat. Salah satunya adalah desa wisata. Desa wisata kini menjadi wisata alternatif dan dinilai strategis dalam menjawab sejumlah agenda dalam pengembangan pariwisata. Pariwisata desa adalah industri yang secara efisien mengintegrasikan alam dan pertanian dengan masyarakat lokal dan pariwisata modern, dan sebagai akibat dari peningkatan urbanisasi yang cepat, daerah pedesaan menjadi pilihan bagi penduduk perkotaan. ${ }^{13}$

Untuk dapat dikatakan sebagai desa wisata, maka sebuah desa perlu memenuhi kriteria sebagai berikut: ${ }^{14}$

1) Memiliki potensi wisata atau produk unik dan khas. Potensi ini dapat berupa potensi fisik (geografis) maupun potensi sosial,

2) Masyarakat yang berkomitmen untuk menyelenggarakan kegiatan pariwisata,

3) Memiliki sumber daya manusia yang cukup,

4) Memiliki peluang atas ketersediaan infrastruktur, dan

5) Kemampuan desa dalam menciptakan pasar wisata.

Keberadaan desa wisata juga tidak kalah penting untuk dikembangkan. Menurut Gamal Suwantoro (2004) Pengembangan pariwisata sering dikaitkan dengan Sapta Pengembangan Kebijakan oleh pemerintah yaitu: Promosi, aksesibilitas, kawasan pariwisata, wisata bahari, produk wisata, sumber daya manusia dan kampanye nasional sadar wisata. ${ }^{15}$ Pengembangan pariwisata

\footnotetext{
${ }^{12}$ Jenny T Chio, A Landscape of Travel: The Work of Tourism in Rural Ethnic China (University of Washington Press 2014).[121].

${ }^{13}$ Yongzhen Zhou, 'Study on the Promotion of Rural Tourism in China's Ethnic Minority Areas: Taking Inner Mongolia Autonomous Region as an Example', Proceedings of the 3rd International Seminar on Education Innovation and Economic Management (SEIEM 2018) (Atlantis Press 2019).[142].

${ }^{14}$ AS Hamzah and M Irfan, 'Law Enforcement Of Constitutional Court Decision No. 69/PUUXII/ 2015 (Mixed Marriage Issue Without Marriage Agreement)’ (2018) 3 Jurnal Notariil.[6-8].

${ }^{15}$ Dewi Nurkhayani and I Made Adikampana, 'Peran Aktor Eksternal Dalam Pengembangan Pariwisata Di Desa Wisata Samiran Kecamatan Selo, Kabupaten Boyolali' (2018) 5 Jurnal Destinasi Pariwisata.[92].
} 
merupakan suatu cara yang dilakukan untuk memajukan dan meningkatkan kepariwisataan suatu daerah yang memiliki daya tarik wisata agar menarik minat wisatawan dan memberikan manfaat bagi masyarakat pada daerah tersebut serta pemerintah tentunya. ${ }^{16}$ Pengembangan pariwisata identik dengan kebijakan yang dikeluarkan pemerintah yaitu Sapta Kebijakan Pemerintah meliputi promosi dan kampanye nasional sadar wisata meliputi Kawasan pariwisata, produk wisata, dan juga sumber daya manusianya dalam suatu daerah pariwisata. ${ }^{17}$

Fungsi pengembangan desa wisata adalah untuk memberikan ruang langsung bagi masyarakat untuk menumbuhkan kesadaran akan adanya peluang wisata potensial. Pengembangan desa wisata juga dapat berfungsi sebagai alat untuk merevitalisasi budaya, tradisi, atau lingkungan tradisional sebagai komoditas wisata, dan memastikan keberadaan berkelanjutan dari budaya dan tradisi ini. ${ }^{18}$ Tidak hanya pelestarian budaya, pengembangan desa wisata ini juga akan mendorong pembangunan ekonomi di desa tersebut. Adanya desa wisata tak dapat dipungkiri dapat berpotensi meminimalkan urbanisasi masyarakat dari pedesaan ke perkotaan, karena masyarakat desa setempat telah mampu mengembangkan desanya sendiri melalui kegiatan pariwisata.

Hal-hal yang menjadikan khas dari suatu desa wisata adalah potensi pemanfaatan desa meliputi entitas masyarakat, alam, dan budaya yang ada di dalamnya sebagai daya tarik wisata. ${ }^{19}$ Oleh karena itu, dalam mengembangkan desa wisata, masyarakat setempat, pemangku kepentingan, dan operator lokal perlu diberikan perhatian yang diperlukan untuk memetakan tradisi masyarakat sebagai kearifan lokal, adat istiadat, musik dan tari, pakaian tradisional, dan makanan khusus. ${ }^{20}$ Desa wisata dalam pengembangannya juga perlu dibimbing agar pelaku

\footnotetext{
${ }^{16}$ Paturusi, Kepariwisataan (Binacipta 2001).[35].

${ }^{17}$ Gamal Suwantoro, Dasar-Dasar Pariwisata (Andi Offset 2004).[24].

${ }^{18}$ Maria Valkova Shishmanova, 'Cultural Tourism in Cultural Corridors, Itineraries, Areas and Cores Networked' (2015) 188 Procedia - Social and Behavioral Sciences.[248].

${ }^{19}$ Abdul Karim, Kapitalisasi Pariwisata: Marginalisasi Masyarakat Lokal Di Lombok (Genta Press 2008).[24].

${ }^{20}$ Courtney Suess, Seyhmus Baloglu and James A Busser, 'Perceived Impacts of Medical Tourism Development on Community Wellbeing' (2018) 69 Tourism Management.[234].
} 
usaha desa wisata dapat menguasai hal-hal berkaitan dengan pariwisata termasuk pada dampak yang akan timbul dari pengembangan tersebut. ${ }^{21}$

Beberapa tahun terakhir, keberadaan desa wisata semakin banyak dan menyebar di hampir seluruh provinsi di Indonesia. Hal ini didorong dengan adanya Program Nasional Pemberdayaan Masyarakat (PNPM) Mandiri Pariwisata oleh pemerintah yang mampu membuka peluang bagi desa-desa untuk mengembangkan potensi sumber dayanya menjadi desa wisata. Langkah lain juga ditempuh pemerintah dalam melakukan pengembangan desa wisata, yakni dengan mengeluarkan kebijakan-kebijakan seperti:

1) Undang-Undang No. 10 Tahun 2008 tentang Kepariwisataan;

2) Undang-Undang No. 11 Tahun 2020 tentang Cipta Kerja;

3) Instruksi Presiden No. 16 Tahun 2005 tentang Kebijakan Pembangunan Kebudayaan dan Pariwisata;

4) Instruksi Presiden No. 6 Tahun 2009 tentang Pengembangan Ekonomi Kreatif;

5) Peraturan Pemerintah No. 5 Tahun 2021 tentang Penyelenggaraan Perizinan Berusaha Berbasis Risiko;

6) Peraturan Pemerintah No. 6 Tahun 2021 tentang Penyelenggaraan Perizinan Berusaha di Daerah;

7) Peraturan Menteri Kebudayaan dan Pariwisata No. KM.18/HM.001/ MKP/2011 tentang Pedoman Program Nasional Pemberdayaan Masyarakat (PNPM) Mandiri Pariwisata;

8) Peraturan Menteri Pariwisata dan Ekonomi Kreatif/ Kepala Badan Pariwisata dan Ekonomi Kreatif Republik Indonesia No. 4 Tahun 2021 tentang Standar Kegiatan Usaha Pada Penyelenggaraan Perizinan Berusaha Berbasis Risiko Sektor Pariwisata.

Pengembangan desa wisata terbagi menjadi 3 (tiga) tahapan yaitu potensi, berkembang, dan maju. ${ }^{22}$ Bicara pada pengembangan potensi desa wisata, maka bicara mengenai tahapan berkembang. Pada tahapan ini, maka sebuah desa telah dikenal dan dikunjungi wisatawan, sedang melaksanakan pembangunan infrastruktur fasilitas pariwisata, dan sedang memulai kegiatan perekonomian dengan memberdayakan masyarakat lokal sebagai tenaga kerja. Namun, dalam

${ }^{21}$ Surya Sakti Hadiwijoyo, Perencanaan Pariwisata Perdesaan Berbasis Masyarakat (Sebuah Pendekatan Konsep) (Graha Ilmu 2012).[17].

${ }^{22}$ Gina Lestari, Armaidy Armawi and Muhamad, ‘Partisipasi Pemuda Dalam Mengembangkan Pariwisata Berbasis Masyarakat Untuk Meningkatkan Ketahanan Sosial Budaya Wilayah (Studi Di Desa Wisata Pentingsari, Umbulharjo, Cangkringan, Sleman, D.I. Yogyakarta)' (2016) 22 Jurnal Ketahanan Nasional.[139]. 
tahapan ini, sebuah desa wisata masih memerlukan bantuan dari para stakeholder baik pemerintah maupun swasta. ${ }^{23}$

Pemerintah dalam mengembangkan desa wisata menggunakan pendekatan pembangunan kepariwisataan berbasis pemberdayaan masyarakat. Hal ini dinyatakan secara tegas dalam Peraturan Menteri Kebudayaan dan Pariwisata No. KM.18/HM.001/MKP/2011 Tentang Pedoman Program Nasional Pemberdayaan Masyarakat (PNPM) Mandiri Pariwisata. Pariwisata berbasis masyarakat sebagai sebuah pendekatan pemberdayaan yang melibatkan dan meletakkan masyarakat sebagai pelaku penting dalam konteks paradigma baru pembangunan yakni pembangunan yang berkelanjutan (sustainable development paradigm) pariwisata berbasis masyarakat merupakan peluang untuk menggerakkan segenap potensi dan dinamika masyarakat, guna mengimbangi peran pelaku usaha pariwisata skala besar. ${ }^{24}$

Mayoritas masyarakat di perdesaan menggantungkan hidupnya dari hasil potensi alam yang ada di daerahnya. Potensi alam tersebut yang kemudian akan dikelola oleh sumber daya masyarakat untuk dijadikan sebagai sumber penghasilan untuk memenuhi kebutuhan ekonomi masyarakat. Adanya potensi lokal yang ada, perlu untuk dioptimalkan baik pengelolaan sumber daya alam maupun sumber daya manusia. Hal inilah yang dimaksudkan dengan pemberdayaan masyarakat, yang bertujuan untuk kemandirian ekonomi di suatu daerah. ${ }^{25}$

Adanya pendekatan pengembangan berbasis masyarakat yang digunakan oleh pemerintah dalam pengembangan desa wisata sejalan dengan konsep yang penting dalam pengembangan pariwisata utamanya desa wisata yaitu konsep pembangunan berkelanjutan. Konsep mengarahkan pada pengembangan pariwisata yang responsif terhadap minat wisatawan dan keterlibatan masyarakat setempat secara langsung. Upaya untuk mengembangkan dan mengelola sumber

\footnotetext{
${ }^{23}$ ibid.

${ }^{24}$ Usman Chamdani, Media Massa E Pariwisata Pedesaan (Budi Utama 2018).[56].

${ }^{25}$ Fitra Ayuningtyas Hidayatullah and Tri Suminar, 'Strategi Pemberdayaan Masyarakat Berbasis Potensi Lokal Candi Plaosan Melalui Program Desa Wisata Untuk Kemandirian Ekonomi Di Desa Bugisan Kecamatan Prambanan Kabupaten Klaten' (2021) 1 Lifelong Education Journal.[3].
} 
daya desa dalam pengembangan desa wisata harus memenuhi kebutuhan ekonomi dan sosial, dengan tetap menjaga integritas dan/atau kelestarian ekologis, keanekaragaman hayati, budaya, dan sistem kehidupan.

\section{Pelaksanaan Online Single Submission (OSS) Pada Izin Usaha Pariwisata}

Setiap usaha yang dijalankan oleh pelaku usaha memerlukan izin melalui prosedur perizinan, termasuk usaha pariwisata. Perizinan merupakan persetujuan dari pemerintah berdasarkan peraturan perundang-undangan terhadap seseorang atau badan hukum yang akan melakukan sebuah Tindakan. ${ }^{26}$ Izin yang diberikan terhadap suatu usaha, merupakan pemberian legalitas pada seseorang atau badan hukum sebagai pelaku usaha. Selain sebagai legalitas, izin berfungsi sebagai sarana pengendalian dan pengawasan dari pemerintah terhadap pelaku usaha. Pasal 15 ayat (1) UU No. 10/2009 jo. UU No. 11/2020 menyatakan bahwa pelaku usaha bidang pariwisata diwajibkan untuk memenuhi perizinan berusaha dari Pemerintah Pusat atau Daerah, sesuai dengan kewenangannya, berdasarkan norma, standar, prosedur, dan kriteria yang ditetapkan oleh Pemerintah Pusat.

Berkenaan dengan usaha pariwisata, maka pelaku usaha pariwisata mengurus izin usaha pariwisata. Pengurusan izin usaha pariwisata ini dilakukan secara terpadu satu pintu, melalui Online Single Submission (OSS). Pemerintah telah mengeluarkan kebijakan mengenai hal ini melalui Peraturan Menteri Pariwisata Nomor 10 Tahun 2018 tentang Pelayanan Perizinan Berusaha Terintegrasi Secara Elektronik Sektor Pariwisata (selanjutnya disebut Permenpar No. 10/2018). Perizinan berusaha terintegrasi secara elektronik merupakan perizinan berusaha yang diterbitkan oleh Lembaga OSS untuk dan atas nama Menteri, pimpinan Lembaga, gubernur, atau bupati/walikota kepada pelaku usaha melalui sistem elektronik yang terintegrasi. System ini disebut dengan Online Single Submission (OSS), sebagaimana diatur dalam Pasal 1 angka 1 Permenpar No. 10/2018.

\footnotetext{
${ }^{26}$ Bagir Manan, Menyongsong Fajar Otonomi Daerah (Pusat Studi Hukum FH UII 2001).[16].
} 
Hal yang utama dalam pengurusan izin usaha pariwisata adalah Tanda Daftar Usaha Pariwisata (TDUP). TDUP wajib dimiliki oleh pulaku usaha di sektor pariwisata untuk mendapatkan kepastian hukum dalam menjalankan usahanya. Pasal 7 ayat (1) Permenpar No. 10/2018 menyatakan TDUP sebagai izin sektor yang diterbitkan oleh lembaga OSS setelah pelaku usaha melakukan pendaftaran untuk memulai kegiatan usahanya, melakukan pelaksanaan komersial atau operasional dengan memenuhi persyaratan dan/atau komitmen (pernyataan pelaku usaha untuk memenuhi persyaratan izin usaha atau izin komersial atau operasional). Pelaku usaha yang dapat mengajukan permohonan TDUP adalah pelaku usaha perseorangan dan/ atau badan hukum yang memiliki Nomor Induk Berusaha (NIB), baik yang telah memiliki, memerlukan, atau tidak memerlukan prasarana dalam menjalankan usaha.

Saat mengurus TDUP, pelaku usaha harus membuat pernyataan untuk memenuhi beberapa izin sebagai komitmen. Izin tersebut meliputi izin lokasi, izin lingkungan, Izin Mendirikan Bangunan (IMB), serta izin lokasi perairan dan izin pengelolaan perairan yang diatur oleh Menteri Kelautan dan Perikanan. Izin lokasi perairan dan izin pengelolaan perairan ini khusus untuk usaha pariwisata yang menggunakan ruang laut secara menetap. Komitmen ini secara tegas diatur dalam Pasal 12 ayat (2) Permenpar No. 10/2018.

Untuk bidang usaha yang membutuhkan TDUP, Pasal 5 ayat (1) Permenpar No. 10/2018 telah mengaturnya. Terdapat 13 bidang usaha pariwisata yang membutuhkan TDUP, yaitu:

Tabel 1. Bidang Usaha Pariwisata yang Membutuhkan Tanda Daftar Usaha Pariwisata (TDUP)

\begin{tabular}{llll}
\hline No. & \multicolumn{1}{c}{ Jenis Usaha } & No. & \multicolumn{1}{c}{ Jenis Usaha } \\
\hline 1. & Daya Tarik wisata & 8. & $\begin{array}{l}\text { Penyelenggaraan pertemuan, } \\
\text { perjalanan intensif, konferensi, } \\
\text { dan pameran }\end{array}$ \\
2. & Kawasan pariwisata & & Jasa informasi pariwisata \\
3. & Jasa transportasi wisata & 10. & Jasa konsultan pariwisata \\
4. & Jasa perjalanan wisata & 11. & Jasa pramuwisata \\
5. & Jasa makanan dan minuman & 12. & Wisata Tirta
\end{tabular}




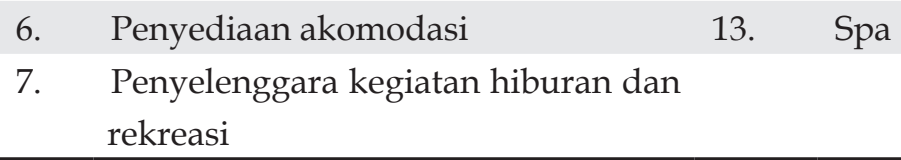

Pengurusan TDUP dilakukan melalui OSS, dengan cara masuk kepada website OSS yaitu http://oss.go.id. Pelaku usaha pariwisata yang wajib menggunakan OSS adalah pelaku usaha perorangan dan/atau badan usaha; usaha kecil, menengah, dan besar; usaha yang berdiri sebelum dan/atau sesudah beroperasinya OSS; dan usaha yang modal seluruhnya berasal dari dalam negeri maupun Sebagian dari asing. Tahapan yang dilakukan pelaku usaha dalam pengajuan permohonan TDUP meliputi:

1) Masuk pada website OSS;

2) Membuat identitas pengguna atau User-ID;

3) Masuk dalam sistem OSS menggunakan User-ID;

4) Mengisi data untuk memperoleh NIB.

Pada tahapan keempat, untuk usaha yang baru berdiri setelah beroperasinya OSS, maka harus menempuh proses pemenuhan komitmen untuk memperoleh izin dasar, izin usaha, izin operasional/komersial. Untuk usaha yang telah berdiri sebelum beroperasinya OSS, maka dapat mengisi data untuk memperpanjang izin berusaha yang sudah ada, mengembangkan usaha, mengubah dan/memperbarui data perusahaan.

Untuk usaha pariwisata di daerah, maka pengurusan perizinan turut mengacu pada Peraturan Pemerintah No. 6 Tahun 2021 tentang Penyelenggaraan Perizinan Berusaha Di Daerah (selanjutnya disebut PP No. 6/2021). Perizinan berusaha di daerah merupakan kegiatan perizinan berusaha yang proses pengelolaannya secara elektronik mulai dari tahap permohonan sampai dengan terbitnya dokumen yang dilakukan secara terpadu dalam satu pintu, yakni OSS. Penyelenggaraan perizinan berusaha di daerah kabupaten/kota dilaksanakan oleh Dinas Penanaman Modal dan Pelayanan Terpadu Satu Pintu (DPMPTSP) kabupaten/kota, sedangkan di daerah provinsi dilaksanakan oleh DPMPTSP provinsi. 
Pelaksanaan pelayanan Perizinan Berusaha di daerah dilengkapi dengan layanan khusus bagi kelompok rentan, lanjut usia, dan penyandang distabilitas dalam mendapatkan jasa pelayanan Perizinan Berusaha. Pengurusan perizinan berusaha di daerah melalui OSS dapat dilakukan secara mandiri oleh pelaku usaha dengan perangkat/fasilitas yang dimilikinya, atau dengan fasilitas yang disediakan oleh DPMPTSP. Pada pelaksanaan perizinan berusaha melalui OSS, dengan perangkat/fasilitas yang disediakan oleh DPMTSP, maka pelaku usaha akan mendapatkan pelayanan bantuan yang dilakukan secara interaktif antara DPMPTSP dengan pelaku usaha. Pelayanan dilakukan dengan mendekatkan keterjangkauan pelayanan kepada Pelaku Usaha dengan menggunakan sarana transportasi atau sarana lainnya.

\section{Kesimpulan}

Potensi suatu desa dapat dikembangkan melalui kepariwisataan. Aspek kepariwisataan tersebut harus digali dan dikembangkan supaya mempunyai daya tarik yang lebih dan memiliki nilai ekonomi yang lebih tinggi. Imbas pengembangan kawasan wisata akan berdampak tidak hanya pada kawasan wisata tersebut dikenal dan dikunjungi oleh masyarakat, namun juga bisa meningkatkan perekonomian dan menggerakkan ekonomi kreatif penduduk desa. Aspek hukum juga harus menjadi perhatian khusus bagi perangkat desa, kelompok sadar wisata dan para pelaku usaha yang terlibat di dalamnya. Perizinan merupakan fondasi awal yang menjadi kewajiban pihak yang melakukan usaha, dengan adanya sistem OSS diharapkan dapat mempermudah para pelaku usaha untuk mengurus suatu perizinan yang dibutuhkan. Hal ini merupakan suatu upaya preventif untuk meminimalisir permasalahan-permasalahan hukum yang timbul.

Tidak hanya aspek perizinan saja, namun kontrak-kontrak yang kerap kali muncul sebagai akibat dari adanya perkembangan sektor wisata yang terkait dengan hubungan-hubungan bisnis juga perlu dipahami. Masyarakat desa, pengembang wisata dan perangkat desa harus membiasakan untuk membingkai segala hubungan bisnis yang terjalin dengan hukum, supaya apabila terjadi suatu 
sengketa di kemudian hari akan jelas posisi masing-masing para pihak berikut juga mengenai tanggung jawab masing-masing pihak.

\section{Daftar Bacaan}

\section{Buku}

Chamdani U, Media Massa E Pariwisata Pedesaan (Budi Utama 2018).

Chio JT, A Landscape of Travel: The Work of Tourism in Rural Ethnic China (University of Washington Press 2014).

Hadiwijoyo SS, Perencanaan Pariwisata Perdesaan Berbasis Masyarakat (Sebuah Pendekatan Konsep) (Graha Ilmu 2012).

Karim A, Kapitalisasi Pariwisata: Marginalisasi Masyarakat Lokal Di Lombok (Genta Press 2008).

Manan B, Menyongsong Fajar Otonomi Daerah (Pusat Studi Hukum FH UII 2001).

Marzuki PM, Penelitian Hukum: Edisi Revisi (Prenada Media 2017).

Paturusi, Kepariwisataan (Binacipta 2001).

Suwantoro G, Dasar-Dasar Pariwisata (Andi Offset 2004).

Tim Percepatan Pengembangan Homestay Desa Wisata, 'Panduan Pengembangan Homestay Desa Wisata Untuk Masyarakat' (2018).

\section{Jurnal}

Firdaus, 'Potency of Integrated Cultural Tourism Development at Maninjau Lake Area, West Sumatera' (2018) 34 MIMBAR : Jurnal Sosial dan Pembangunan.

Hamzah AS and Irfan M, 'Law Enforcement Of Constitutional Court Decision No. 69/PUU-XII/ 2015 (Mixed Marriage Issue Without Marriage Agreement)' (2018) 3 Jurnal Notariil.

Hidayatullah FA and Suminar T, 'Strategi Pemberdayaan Masyarakat Berbasis Potensi Lokal Candi Plaosan Melalui Program Desa Wisata Untuk Kemandirian Ekonomi Di Desa Bugisan Kecamatan Prambanan Kabupaten Klaten' (2021) 1 Lifelong Education Journal.

Lestari G, Armawi A and Muhamad, 'Partisipasi Pemuda Dalam Mengembangkan 
Aktieva Tri, dkk: Legalitas Perizinan Kawasan...

Pariwisata Berbasis Masyarakat Untuk Meningkatkan Ketahanan Sosial Budaya Wilayah (Studi Di Desa Wisata Pentingsari, Umbulharjo, Cangkringan, Sleman, D.I. Yogyakarta)' (2016) 22 Jurnal Ketahanan Nasional.

Minardi A and others, 'Indonesian Tourism Diplomacy to India' (2020) 1 Indonesian Journal of Tourism and Leisure.

Nurkhayani D and Made Adikampana I, 'Peran Aktor Eksternal Dalam Pengembangan Pariwisata Di Desa Wisata Samiran Kecamatan Selo, Kabupaten Boyolali' (2018) 5 Jurnal Destinasi Pariwisata.

Shishmanova MV, 'Cultural Tourism in Cultural Corridors, Itineraries, Areas and Cores Networked’ (2015) 188 Procedia - Social and Behavioral Sciences 246.

Suess C, Baloglu S and Busser JA, 'Perceived Impacts of Medical Tourism Development on Community Wellbeing' (2018) 69 Tourism Management.

Yuliati Eand Suwandono D, 'Arahan Konsep Dan Strategi Pengembangan Kawasan Desa Wisata Nongkosawit Sebagai Destinasi Wisata Kota Semarang' (2016) 2.

\section{Prosiding}

Zhou Y, 'Study on the Promotion of Rural Tourism in China's Ethnic Minority Areas - - Taking Inner Mongolia Autonomous Region as an Example', Proceedings of the 3rd International Seminar on Education Innovation and Economic Management (SEIEM 2018) (Atlantis Press 2019).

\section{Karya yang Tidak Diterbitkan}

Mahadiansar, 'Implementasi Kebijakan Pengembangan Pariwisata Berkelanjutan Berbasis Network Governance (Studi Di Kabupaten Bintan, Provinsi Kepulauan Riau)' (Universitas Brawijaya 2021).

\section{Laporan}

Badan Pariwisata dan Ekonomi Kreatif Republik Indonesia, 'Laporan Tahunan Kementerian Pariwisata Dan Ekonomi Kreatif 2016-2020’ (2020).

\section{Laman}

Badan Koordinasi Penanaman Modal, ‘OSS/Sistem Pelayanan Perizinan Berusaha Terintegrasi Secara Elektronik' https://oss.go.id/.

Pemerintah Desa Gerbo, 'Sejarah Desa Gerbo' < https://pemerintahdesagerbo. blogspot.com/2020/09/profil-desagerbo_7.html?m=1>. 


\section{Perundang-undangan}

Undang-Undang Nomor 10 Tahun 2009 tentang Kepariwisataan (Lembaran Negara Republik Indonesia Tahun 2009 Nomor 11).

Undang-Undang Nomor 11 Tahun 2020 tentang Cipta Kerja (Lembaran Negara Republik Indonesia Tahun 2020 Nomor 245).

Instruksi Presiden Nomor 16 Tahun 2005 tentang Kebijakan Pembangunan Kebudayaan dan Pariwisata.

Instruksi Presiden Nomor 6 Tahun 2009 tentang Pengembangan Ekonomi Kreatif.

Peraturan Pemerintah Nomor 5 Tahun 2021 tentang Penyelenggaraan Perizinan Berusaha Berbasis Risiko.

Peraturan Pemerintah Nomor 6 Tahun 2021 tentang Penyelenggaraan Perizinan Berusaha di Daerah.

Peraturan Menteri Kebudayaan dan Pariwisata Nomor KM.18/HM.001/ MKP/2011 tentang Pedoman Program Nasional Pemberdayaan Masyarakat (PNPM) Mandiri Pariwisata.

Peraturan Menteri Pariwisata dan Ekonomi Kreatif/ Kepala Badan Pariwisata dan Ekonomi Kreatif Republik Indonesia Nomor 4 Tahun 2021 tentang Standar Kegiatan Usaha Pada Penyelenggaraan Perizinan Berusaha Berbasis Risiko Sektor Pariwisata.

How to cite: Aktieva Tri Tjitrawati, Rizky Amalia, Fairuz Zahirah Zihni Hamdan, 'Legalitas Perizinan Kawasan Wisata Sebagai Upaya Pengembangan Desa Wisata' (2022) Vol. 5 No. 1 Media Iuris. 
--Halaman ini sengaja dibiarkan kosong-- 